\title{
ANALISIS RASIO KEUANGAN UNTUK MENILAI KINERJA KEUANGAN PADA PT. INDOFOOD SUKSES MAKMUR, Tbk, DI BURSA EFEK SURABAYA (BES) \\ PERIODE 1998 - 2002
}

\section{VeronikaNugraheni Sri Lestari}

Fakultas Ekonomi - Universitas Dr. Soetomo - Surabaya

Analisis keuangan merupakan dasar untuk menilai dan menganalisis prestasi dari perusahaan yang disamping itu dapat digunakan sebagai kerangka kerja perusahaan dan pengendalian keuangan. Analisa keuangan mencakup analisa rasio keuangan serta analisa kelemahan dan kekuatan di bidang keuangan akan sangat membantu didalam menilai prestasi operasional dan manajemen di masa lalu dan prospeknya di masa depan.

Dengan analisa keuangan akan dapat diketahui kekuatan dan kelemahan yang dimiliki oleh business enterprise, rasio keuangan tersebut dapat memberikan indikasi apabila perusahaan memiliki kas yang cukup untuk memenuhi kewajiban keuangannya, besarnya pintang yang cukup rasional, efisiensi manajemen persediaan, perencanaan pengeluaran investasi yang baik, dan struktur modal yang sehat.

Keyword : analisa, rasio keuangan

\section{Latar Belakang}

\subsection{Latar Belakang}

Pada saat ini banyak perusahaan telah menjual sahamnya ke pasar modal atau go publik. Hal ini berarti bahwa perkembangan pasar modal patut diharapkan sebagai salah satu indikator pembangunan ekonomi; dalam rangka mengimpundana baik untuk memperlancar proses produksi maupun untuk berinvestasi.

Adapun faktor yang mendasar yang ingin dituju oleh setiap pasar modal adalah keterbukaan informasi, khususnya informasi mengenai laporan keuangan perusahaan, keterbukaan di dalam penyampaian informasi keuangan ini dimaksudkan agar setiap pihak 
Veronica Nugraheni Sri Lestari

diluar perusahaan terutama calon pemegang saham maupun calonkreditur akan memperoleh gambaran yang lengkap mengenai prospek dan kinerja perusahaan-perusahaan yang ingin menjual sahamnya kepada masyarakat luas serta kondisi penting lainnya yang dapat dijadikan sebagai bahan pertimbangan dalam mengambil keputusan untuk membeli ataupun memberikan pinjaman kepada perusahaan yang bersangkutan.

Salah satu analisa yang dapat dijadikan sebagai bahan pengambilan keputusan bagi calon pemegang saham dan calon kreditur adalah dengan membandingkan kinerja perusahaan dari tahun ke tahun, hasil keputusan dari para calon pemegang saham dan calon kreditur tersebut didasarkan dari apakah kinerja perusahaan semakin meningkat atau sebaliknya? Apabila kinerja perusahaan meningkat dari tahun ke tahun maka akan mendorong investoruntuk menanamkan modalnya ke perusahaan tersebut.

Di lain pihak untuk membuat keputusan rasional yang sesuai dengan tujuan perusahaan, maka seorang manajer keuangan juga harus mempunyai alat dan analisis tertentu.
Analisis keuangan merupakan dasar untuk menilai dan menganalisis prestasi dari perusahaan yang di samping itu, dapat digunakan sebagai kerangka kerja perusahaan dan pengendalian keuangan. Analisa keuangan mencakup analisa rasio keuangan serta analisa kelemahan dan kekuatan di bidang keuangan akar sangat membantu di dalam menilai prestasi operasional dan manajemen di masa lalu dan prospeknya di massa mendatang.

Dengan analisa keuangan akan dapat diketahui kekuatan dan kelemahan yang dimiliki oleh business enterprise, rasio keuangan tersebut dapat memberikan indikasi apabila perusahaan memiliki kas yang cukup untuk memenuhi kewajiban keuangannya, besarnya piutang yang cukup rasional, efisiensi manajemen persediaan, perencanaan pengeluaran investasi yang baik, dan struktur modal yang sehat. Dengan menilai prestasi keuangan maka seorang analisis keuangan dapat merencanakan dan mengimplementasikan ke dalam setiap tindakan secara konsisten dengan tujuan memaksimumkan kemakmuran pemegang saham. 
PT. Indofood Sukses Makmur

Tbk, yangsahamnya terdaftar di Bursa

Efek Surabaya merupakan objek penelitian kami dan merupakansalah satu perusahaan yang bergerak di bidangindustri makanan di Indonesia dan merupakanprodusen mie instant terbesar di dunia.

\subsection{Perumusan Masalah}

Analisis rasio keuangan sebagai alat bagi manajemen dalam menilai kinerja perusahaan, ternyata sangat dibutuhkan oleh pemakai informasilaporan keuangan yaitu pihak manajemen perusahaan dan para calon investor.

Berdasarkan latar belakang tersebut maka rumusan masalah : "Bagaimanakah kinerja keuangan PT. Indofood Sukses Makmur, Tbk, dari tahun 1998 sampai tahun 2002?”.

\subsection{Tujuan Penelitian}

1. Untuk mengukur kinerja perusahaan dengan menggunakan analisis rasio.

2. Untuk mengetahui dan mengevaluasi kinerja keuangan PT. Indofood Sukses Makmur Tbk, dari tahun 1998 sampai tahun

$$
\begin{aligned}
& \text { 2002, sebagai salah satu } \\
& \text { pedoman bagi pihak yang } \\
& \text { berkepentingan } \\
& \text { mengambil keputusan. }
\end{aligned}
$$

\subsection{Manfaat Penelitian}

1. Pengembangan ilmu

Hasil penelitian dapat digunakan sebagai referensi ilmiah dan memperluas khasanah ilmu pengetahuan yang diharapkan dapat membantu para peneliti berikutnya, sehingga dapat lebih disempurnakan.

2. Operasional

Hasil penelitian ini diharapkan dapat digunakan sebagai suatu dasar yang dapat dipakai dalam mengevaluasi kinerja keuangan perusahaan yang mana diharapkan agar di masa mendatang kinerja keuangan dapat lebih ditingkatkan.

\subsection{Tinjauan Pustaka \\ Laporan keuangan merupakan salah satu sumber informasi penting bagi para pemakai laporan keuangan dalam rangka pengambilan keputusan.Pada sisi lain ternyata bahwa karena karakteristiknya, laporan}


Veronica Nugraheni Sri Lestari

keuangan bukanlah satu satunya alat dan sumber informasi yang diperlukan pimpinan perusahaan karena laporan keuangan mempunyai keterbatasan. Laporan keuangan akan menjadi lebih bermanfaat untuk pengambilan keputusan apabila dengan informasi laporan keuangan tersebut dapat diprediksi apa yang akan terjadi di masa yang akan datang.

Menurut pendapat Ridwan S. Sundjajadan IngeBarlian (2003 : 128) mengatakan bahwa : "Laporan keuangan merupakan bagian dari proses pelaporan keuangan yang terdiri dari laporan 1aba rugi, neraca, laporan laba ditahan dan laporan aliran kas."

Pendapat dari Ray H Garrison (2000: 476) "Laporan keuangan merupakan dokumen historis, laporan keuangan memberitahu apa telah terjadi selama tahun tertentu atau serangkaian tahun tertentu."

Sedangkan menurut pendapat $\mathrm{J}$. Fred Westea dan Thomas E. Copeland (24) "Laporan keuangan merupakan laporan tentang prestasi historis dari suatu perusahaan dan memberikan dasar bersama dengan analisis bisnis dan ekonomi untuk membuat proyeksi atau peramalan untuk masa depan.

Pengukuran kinerja diperlukan untuk mengetahui kondisi dan prestasi keuangan perusahaan sehingga dapat membantu pihak-pihak yang berkepentingan terhadap perusahaan dalam membuat keputusan.Penilaian kinerja perusahaan merupakan suatu pedoman untuk mengetahui dan menilai sebuah perusahaan yang ditunjukkan oleh laba perusahaan selama periode tertentu.Kinerja tersebut sangat erat hubungannya dengan produksi atas manajemen perusahaan.

Pendapat dari Mulyadi (2001 :415) bahwa "Kinerja adalah penentuan secara periodik efektivitas operasional suatu organisasi, bagian organisasi dan karyawannya berdasarkan sasaran standar dan kriteria yang kriteria ditetapkan sebelumnya."

Dan menurut MenKeu Republik Indonesia No. 740/KMK.00/1989 bahwayang dimaksud dengan "Kinerja adalah Prestasi yang dicapai oleh perusahaan dalam suatu periode tertentu yang mencerminkan tingkat kesehatan dari perusahaan tersebut." 


\section{METODE PENELITIAN}

\subsection{Operasionalisasi Variabel dan Pengukurannya}

Kinerja keuangan adalah sehat atau tidaknya keuangan suatu perusahaan di mana rasio rata-rata perusahaan lebih besar dari pada ratarata industri.Untuk menilai kinerja perusahaan dengan menggunakan alat ukur rasio keuangan baik rasio likuiditas, solvabilitas, profitabilitas dan aktivitas.

Analisis rasio keuangan merupakan suatu proses untuk menilai kemampuan perusahaan di dalam melakukan operasionalnya yang berkesinambungan. Penilaian tersebut dilakukan dengan menganalisa laporan keuangan (neraca dan laporan rugi laba) selama dua tahun, gunamenilai kinerja keuangan perusahaan di masa lalu, saat ini dan prospeknyadi masa yang akan datang

Alat ukur analisa rasio keuangan yang digunakan terdiridari :

1. Rasio likuiditas adalah rasio yang menunjukkan kemampuan perusahaan dalam memenuhi semua kewajiban finansial jangka pendek yang sudah jatuh tempo.
2. Rasio solvabilitas adalah rasio yang mengukur kemampuan perusahaan memenuhi kewajibannya sekiranya perusahaan dilikuidasi.

3. Rasio profitabilitas adalah rasio yang digunakan seberapa besar kemampuan perusahaan memperoleh laba baik dalam hubungannya dengan asset ataupun laba bagi modal sendiri.

4. Rasio aktivitas adalah rasio yang menunjukkan sejauh mana efisiensi perusahaan dalam memanfaatkan sumber daya secara optimal.

\subsection{Teknik Pengumpulan Data}

Jenis data yang digunakan dalam penelitian ini adalah data sekunder, yaitu data yang sudah ada.Jadi bukan diusahakan oleh penulis data ini berupa laporan keuangan dari perusahaan yang dijadikan objek penelitian yang terdiri atas neraca den laporan rugi laba. Data diperoleh dari catatan instansi hang berhubungan dengan masalah perusahaan yaitu dari pusat referensi pasar modal (PRPM) di Surabaya selama periode pengamatan tahnn1998 sampai dengan 2002. 
Veronica Nugraheni Sri Lestari

\subsection{TeknikAnalisis}

Analisis data dilakukan secara kualitatif yaitu membandingkan rasiorasio keuangan perusahaan tahun 1998 sampai dengan 2002 kemudian menginterpretasikannya.

$$
\text { Rasio-rasio }
$$
yang

dimplementasikanadalah :

1. Rasio Liktuclitas

Rasio ini digunakan untuk mengetahui kemampuan perusahaan untuk memenuhi semua kewajiban finansial jangka pendek rang sudah jatuh tempo

a. Current Ratio $=\frac{\text { Aktiva Lancar }}{\text { Kewajiban Lancar }}$

b. Quick Ratio $=\frac{\text { Aktiva Lancar }- \text { Persediaan }}{\text { Kewajiban Lancar }}$

2. Rasio Solvabilitas

Rasio ini digunakan untuk mengetahui proporsi atas penggunaan utang untuk membiayai investasinya.

a. Debit Ratio $=\frac{\text { Total Kewajiban }}{\text { Total Aktiva }}$

b. Debt to Equity Ratio $=\frac{\text { Total Kewajiban }}{\text { Total Modal Sendiri }}$

3. Rasioprofitabilitas

Rasio ini digunakan untuk mengetahui kemampuan perusahaan untuk memperoleh laba dalam hubungannya dengan total aktiva maupun modal sendiri.

Volume VII No. 2 Juni 2006 a. Return on Investment $=\frac{\text { Laba Setelah Pajak }}{\text { Total Aktiva }}$

b. Return on Equity $=\frac{\text { Laba Setelah Pajak }}{\text { Modal Sendiri }}$

4. Rasio Aktivitas

Rasio ini menunjukkan bagaimana sumber daya yang dimiliki dimanfaatkan secara optimal.

a. Fixed asset turn over $=\frac{\text { Penjualan }}{\text { Aktiva Tetap }}$

b. Total asset turn over $=\frac{\text { Penjualan }}{\text { Total Aktiva }}$

III. Hasil Penelitian dan Pembahasan

Bertitik tolak dan permasalahan yang dihadapi PT.Indofood Sukses Makmur Tbk, yaitu untuk mengetahui adanya kenaikan dan penurunan kinerja perusahaan dengan membandingkan laporan keuangan dari periode tahun berjalan dengan periode tahun sebelumnya.

Laporan keuangan perusahaan merupakan salah satu sumber informasi yang penting dalam mengambil suatu keputusan. Tetapi suatu laporan keuangan akan kurang mempunyai arti apabila tidak dapat dianalisis. Analisis rasio keuangan adalah salah satu alat untuk menganalisis laporan keuangan suatu perusahaan dan untuk mengetahui kondisi keuangan suatu perusahaan serta kinerja perusahaan ditinjau dari keuangannya.Bagi para investor,analisis 
rasio keuangan merupakan indikator yang penting untuk mengetahui kesehatan perusahaandari posisi relatif perusahaan.Dengan mengetahui kesehatan perusahaan maka para investor dapat melakukan transaksi pembelian saham untuk perusahaan yang sehat dan mempunyai prospek keuntungan di masa mendatang.Dengan demikian investor dapat mencapai keuntungan yang optimal baik berupa deviden maupun capitalgain.

Berdasarkan penjelasan di atas, maka untuk menganalisa rasio keuangan sebagai alat untuk menilai kinerja keuangan perusahaan pada periode 1998 sampai dengan 2002 di Bursa Efek Surabaya dapat ditampilkan pada tabel di bawah ini:

Tabel

Analisis Rasio Keuangan

PT. Indofood Sukses Makmur, Tbk

Tahun 1998 - 2002

\begin{tabular}{|c|c|c|c|c|c|c|c|c|}
\hline Tahun & $\begin{array}{c}\text { Current } \\
\text { Ratio }\end{array}$ & $\begin{array}{c}\text { Quick } \\
\text { Ratio }\end{array}$ & $\begin{array}{c}\text { Deb } \\
\text { Ratio }\end{array}$ & $\begin{array}{c}\text { Debt } \\
\text { to } \\
\text { Equity }\end{array}$ & ROI & ROE & $\begin{array}{c}\text { Fixed } \\
\text { Assets } \\
\text { Turn } \\
\text { Over }\end{array}$ & $\begin{array}{c}\text { Total } \\
\text { Assets } \\
\text { Turn } \\
\text { Over }\end{array}$ \\
\hline & & & & & & & & \\
1998 & $119 \%$ & $88 \%$ & $90 \%$ & $15 \%$ & $3 \%$ & $45 \%$ & 1,46 & 0,82 \\
1999 & $89 \%$ & $62 \%$ & $72 \%$ & $320 \%$ & $14 \%$ & $63 \%$ & 1,89 & 1,09 \\
2000 & $130 \%$ & $82 \%$ & $70 \%$ & $289 \%$ & $6 \%$ & $25 \%$ & 1,74 & 1,01 \\
2001 & $87 \%$ & $51 \%$ & $67 \%$ & $243 \%$ & $7 \%$ & $26 \%$ & 1,89 & 1,13 \\
2002 & $164 \%$ & $101 \%$ & $70 \%$ & $242 \%$ & $6 \%$ & $25 \%$ & 2,03 & 1,00 \\
& & & & & & & & \\
\hline
\end{tabular}

Dari hasil analisa perhitungan rasio keuangan yang didasarkan pada laporan keuangan diatasmenunjukkan :

1. Terdapat adanya pertumbuhan kinerja keuangan pada perusahaan di berbagai aspek finansial. Hal tersebut dikarenakan kinerja keuangan PT. Indofood Sukses Makmur Tbk, apabila ditinjau dari tingkat likuiditas, pertumbuhan kinerja keuangan perusahaan cukup bagus terjadi pada tahun 2002 dimana tingkat current ratioperusahaan mencapai $164 \%$ dan merupakanpeningkatan terbesar dalam kurun waktu limatahun dimana pada tahun-tahun sebelumnyaselalu mengalami penurunan yang cukup besar,hal ini disebabkan karena tingkat 
Veronica Nugraheni Sri Lestari

kewajibanlancar yang cukup besar

dibandingkan dengantingkat aktiva

yang dimiliki perusahaan

misalkanpada tahun 2001 dimana

pada tahun ini terjadipenurunan

yang cukup besar. Selisih dan

tahun2002 yaitu sebesar

$77 \%$.Sedangkan dalam tingkatquick

ratio pada tahun 2002

merupakanpeningkatan terbesar

yaitu sebesar 101\%.Halini

disebabkan karena tingginya nilai

aktiva lancardibandingkan

kewajiban lancar perusahaan

setelah dikurangi persediaan. Dan

sini dapat dilihat bahwa dalam

usahanya untuk meningkatkan

kinerja keuangan perusahaan

khususnya pada tingkat likuiditas

seharusnya perusahaan mengurangi

tingkat hutang kepada pihak lain

dan berusaha meningkatkan aktiva

lancar khususnya aktiva yang lebih

likuid seperti kas, surat berharga,

piutang dan persediaan, sehingga

mampu membayar kewajiban

finansial jangka pendek tepat

padawakktunya.

2. Kinerja keuangan PT. Indofood

Sukses Makmur Tbk, apabila

ditinjau dari tingkatsolvabilitas dalam kurun waktu 5 tahun debt to

rasio perusahaan terus mengalami

penurunan hal ini disebabkan

karena tingginya tingkat pinjaman

perusahaan yang mencapai

2.094.667.729.403 di tahun 2001

pada tingkat debt to equity ratio,

kinerja keuangan perusahaan

mengalami penurunan dan

peningkatan. Debtto equity ratio

terbesar terjadi pada tahun 1999

sebesar $320 \%$ dan terus menurun

dari tahun ke tahun, hal ini terjadi

karena pergeseran kepemilikan atas

modal sendiri yang semakin tinggi,

untuk mengatasi masalah

penurunan tingkat solvabilitas,

perusahaan seharusnya jangan

tergantung pada pihak kedua dalam

pembiayaan proyek-proyek

perusahaan dengan tingkat resiko yang cukup besar sehingga perusahaan akan kesulitan dalam pengembalian hutang yang digunakan untuk investasi tepat pada waktunya. Kinerja keuangan PT. Indofood Sukses Makmur Tbk, apabila ditinjau dari tingkat profitabilitas pada tahun 1999 tingkat return on investment perusahaan mencapai $14 \%$. dan 
menurun terjadi pada tahun-tahun berikutnya. Hal senada terjadi pada tingkat return on equity yang mencapai angka tertinggi sebesar 63\%. Angka tersebut mengidentifikasikan bahwa perusahaan besar mampu meningkatkan profitabilitas perusahaan.Hal ini menyebabkankeuntungan bagi para pemegang saham dan sebaiknya perusahaan mempertahankan kondisiseperti pada saat ini untuk diterapkan padatahun-tahun berikutnya dan berusaha untuk lebih ditingkatkan.

4. Kinerja keuangan PT. Indofood Sukses Makmur Tbk, apabila ditinjau dari tingkat aktivitas dalam kurun waktu 5 tahun fixed assets turn over perusahaan mengalami peningkatan dari tahun ke tahun. Kenaikan terbesar pada tahun 2002 yaitu sebesar 2.03 kali dan untuk total assets turn over perusahaan juga mengalami peningkatan dari tahun ke tahun, dan peningkatan terbesar terjadi pada tahun 2001 yaitu sebesar 1.13 kali. Hal ini menunjukkan bahwa perusahaan sudah efisien dalam menghasilkan penjualan serta mampu menciptakan volume bisnis yang lebih luas untuk ukuran investasi yang dimilikinya.Apabila ditinjau dari tingkat aktivitas diatas seharusnya perusahaan tetap mempertahankan kondisi ini dan kalau bisa lebih ditingkatkan lagi.

\section{Simpulan}

Berdasarkan hasil perhitungan dan analisa dapat disimpulkan:

1. Berdasarkan latar belakang ekonomi, pesaing danperusahaan menandakan bahwa perusahaan mampu bersaing dan mempunyai beberapa keistimewaan yang bisa meningkatkan kinerja perusahaan.

2. Tingkat likuiditas PT Indofood Sukses Makmur cukup baik hal ini dibuktikan dengan meningkatkan pos-pos aktiva lancar dari tahun ke tahun hasil yang telah dicapai tentunya akansangat mengembangkan bagi perusahaan.

3. Kemampuan perusahaan untuk melunasi kewajiban jangka panjang cukup baik, sehingga tidak membahayakan dana yang ditanam oleh peranan modal. Hal ini menguntungkan pihak eksternal, 
Veronica Nugraheni Sri Lestari

terutama para investor karena

umumnya mereka berinvestasi

dalam jangka panjang.

4. Kurangnya kemampuan perusahaan dalam menghasilkan laba atas penggunaan hutang secara optimal karena proporsi penggunaan hutang untuk membiayai investasi semakin menurun.

5. Profitabilitas dan aktivitas perusahaan cukup baik dan optimal, meskipun tingkat profitabilitas tidak terlalu tinggi, tetapi tingkat kemampuan pemanfaatan sumber daya yang dimiliki sudah optimal.

\section{DAFTAR PUSTAKA}

Garrison, Ray H, Akuntansi Manajemen, Terjemahan Bambang Purnomosidhi dan ErwanDukat, Yogyakarta: AK Group, 2000.

Keown, ArturJ. David F Scoot. Jr, John D. Martin, dau William Petty, Dasar-Dasar Manajemen Keuangan, Terjemahan Chaerul D. Djakman, Jakarta: Salemba Empat, 2001.

Machfoedz, Mas'ud,Akuntansi Manajemen,Yogyakarta: BPFE, 1994.

Mulyadi, Akuntansi Manajemen, Jakarta: Salemba Empat, 2001.
Nafarin M, Penganggaran Perusahaan, Jakarta Salemba Empat, 2004.

Rahardjo Budi, Akuntansi Keuangan Untuk Manajer Non Keuangan, Yogyakarta, Andi, 2000.

Riyanto, Bambang, Dasar-Dasar Pembelajaran Perusahaan, Yogyakarta: Yayasan Penerbit Gadjah Mada, 1992.

Sartono, Agus, Manajemen Keuangan, Yogyakarta: BPFE,1996.

Siegel, Joel B. dan Jae K. Slum, Mengatur Keuangan, Jakarta: PT Elex Media Komputindo, 1993.

Sundjaya, Ridwan S. dan IngeBarlian, Manajemen Keuangan, Bandung:Literata Lintas Media, 2003.

Syamsuddin, Lukman, Manajemen Keuangan Perusahaan, Jakarta Rasa Orafindo Persada,1994.

Wahyono, HadiJurnal Riset Ekonomi dan Manajemen, Surabaya, Editor Jurnal Riset Ekonomi dan Manajemen, 2002.

Weston, J. Fred dan Thomas E. Copeland, Manajemen Keuangan, Jakarta: Binarupa Aksara,1995. 